\title{
Effect of a mixture of paint and Rhizophora mucronata leaves extract as a natural inhibitor of marine steel in $3.5 \% \mathrm{NaCl}$ solution
}

\author{
Wajilan, ${ }^{1}$ A. Fernandes ${ }^{2}$ (D) and A. Wahyudianto ${ }^{1}$ (D) \\ ${ }^{1}$ Politeknik Negeri Samarinda, Jl. DR Ciptomangunkusumo, Kampus Gunung Lipan, \\ Samarinda, East Kalimantan, Indonesia \\ ${ }^{2}$ Dipterocarps Research Center, Jl. A W Syahranie no. 68, Sempaja, Samarinda, \\ East Kalimantan, Indonesia \\ *E-mail: arif.wahyudianto@polnes.ac.id
}

\begin{abstract}
Marine steel is steel used in marine environments, such as steel for offshore construction and ships. Marine steel is easily corroded. To increase the corrosion resistance of marine steel, paints can be mixed with natural inhibitors, such as Rhizophora mucronata leaves extract. This study aimed at determining the effect of a mixture of paint and Rhizophora mucronata leaves extract as a corrosion inhibitor on marine steel. The GC-MS test was performed to determine the content of chemical compounds in Rhizophora mucronata leaves extract. Emission spectroscopy testing was carried out to determine marine steel elements. The corrosion inhibitor was prepared by making a mixture of paint and concentrated Rhizophora mucronata leaves extract with concentrations of $10,20,30$, and $40 \%$ by volume. A potentiostat/galvanostat (PGSTAT101) was utilized to acquire anodic and cathodic polarization curves for marine steel in $3.5 \% \mathrm{NaCl}$ solution. Based on GC-MS test results, Rhizophora mucronata leaves extract contain chemical compounds that can coat and inhibit the surface oxidation process of marine steel. Based on emission spectroscopy, marine steel specimen contained $98.56 \% \mathrm{Fe}, 0.316 \% \mathrm{C}, 0.26 \mathrm{Si}$ and $0.655 \mathrm{Mn}$. The paint mixture with Rhizophora mucronata leaves extract could reduce the corrosion rate to $0.000112485 \mathrm{~mm} /$ year in $3.5 \% \mathrm{NaCl}$ solution. The paint-coated specimens with all the concentrations of Rhizophora mucronata leaf extract had almost the same percentage increase in inhibitor efficiency (\% IE), 97.86-98.96\%. Therefore, the use of a mixture of the paint with $20 \%$ Rhizophora mucronata leaves extract was taken as the optimal composition.
\end{abstract}

Received: May 24, 2021. Published: October 14, 2021

doi: $10.17675 / 2305-6894-2021-10-4-5$

Keywords: Rhizophora mucronata leaves extract, marine steel, inhibitor, corrosion.

\section{Introduction}

Steel is most widely used in the construction sector, around 50\%, the transportation sector, such as cars, planes, and other vehicles, and 14\% in industrial machinery [1]. Steel is also widely used in marine environments. It is known as marine steel, for example, steel used in 
onshore and offshore buildings, ships, oil and gas facilities [2]. Much marine steel is used in docks, and ships. Various other types of steel are used in marine environments in archipelagic countries, such as Indonesia. Marine steel is easily corroded, so it needs to be given a corrosion-protective coating such as paint. The use of paint in coating marine steel for a long period can produce toxic agents [3]. To increase the corrosion resistance and reduce the release of toxins, paints can be mixed with natural inhibitors.

The "green chemistry" movement is attempting to ensure the environment and human wellbeing, including discovering inhibitors that are effectively biodegradable, harmless to the ecosystem, and simple to renew [4]. Natural inhibitors can be obtained especially from plants [5].

Rhizophora mucronata is a species of plant that is commonly found in mangrove forests. Rhizophora mucronata leaves contain phenolic compounds [6] which may function as natural inhibitors. Rhizophora leaves are good candidates for natural inhibitors because it is easy to renew, harmless to the ecosystem and biodegradable. This research aimed to determine the effect of a mixture of paint and Rhizophora mucronata leaves extract as a corrosion inhibitor on marine steel.

\section{Materials and Methods}

\subsection{Rhizophora mucronata leaves extract}

Mangrove (Rhizophora mucronata) leaves utilized in this research were taken from Balikpapan mangrove forests. The mangrove leaves are dried at room temperature for a month. Air-dried mangrove leaves have a $15.06 \%$ moisture content. 500 grams of mangrove leaves were cut into small pieces and put into a glass beaker. $500 \mathrm{ml}$ of $96 \%$ ethanol was added to the beaker. The beaker was covered and stored at room temperature for 48 hours. The extract was filtered and concentrated to $100 \mathrm{ml}$.

The GC-MS test was performed using $10 \mathrm{ml}$ of the concentrated extract. The GC-MS test aims to determine the content of chemical compounds in the extract. $90 \mathrm{ml}$ of concentrated extract was used as a natural inhibitor to be mixed with a paint (natural oil, white organic pigment, and thinner) to coat marine steel for corrosion testing.

\subsection{Marine steel plates}

Emission spectroscopy testing was carried out to determine the marine steel elements.

\subsection{Polarisation study}

The corrosion inhibitor was prepared by making a mixture of paint and Rhizophora mucronata leaves concentrated extract. Mixture with concentrations of 10, 20, 30, and 40\% by volume were made. Marine steel was cut into $10 \times 10 \times 2 \mathrm{~mm}$ coupons. One of the marine steel surfaces was covered with a resin so the corrosion test was focused on one surface. A mixture of the paint with concentrated mangrove extract was applied to the uncovered surface of the marine steel and left to dry for 24. 
A potentiostat/galvanostat (PGSTAT101) was utilized to record anodic and cathodic polarization curves [7] for marine steel with various concentrations of the paint and Rhizophora mucronata leaves concentrated extract in $3.5 \% \mathrm{NaCl}$ solution. $3.5 \% \mathrm{NaCl}$ was used on a lab scale to replace seawater [8]. Research was done by recording marine steel corrosion rate curves and polarization curves.

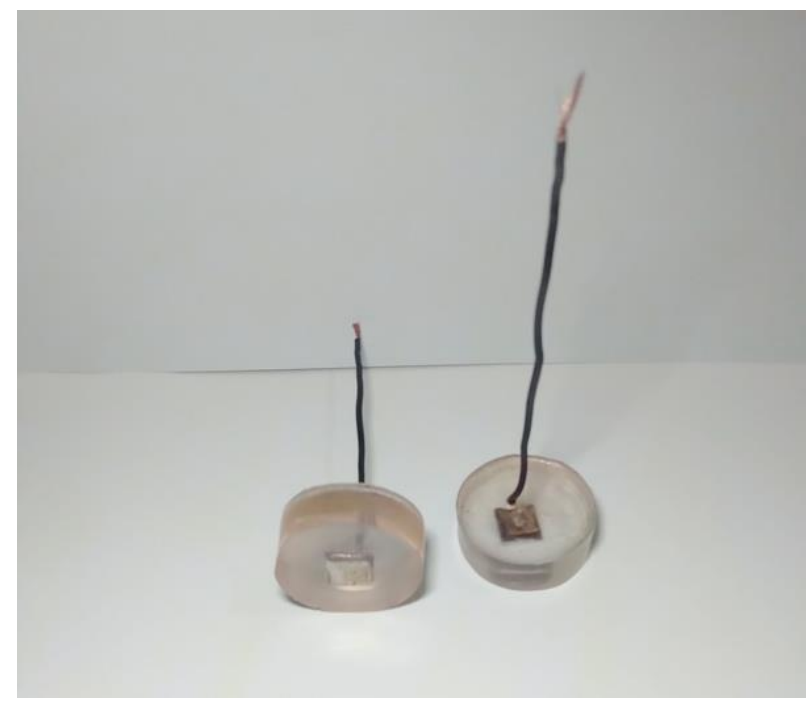

Figure 1. Corrosion test specimens.

\subsection{Marine steel surface microscopic structure}

The microscopic structure was determined to characterize the corroded marine steel surface after the polarisation study.

\section{Results and Discussion}

\subsection{Rhizophora mucronata extract characteristics}

The GC-MS test results of Rhizophora mucronata leaves extract are presented in Figure 1 and Table 1.

A natural corrosion inhibitor may contain aromatic rings, $\mathrm{N}-, \mathrm{S}-, \mathrm{O}-, \mathrm{P}-$ and heterocyclic moieties [9]. Based on GC-MS test result from Table 1, the Rhizophora mucronata leaves extract contains 11 chemical compounds which had cyclic structures and $\mathrm{O}$-structures, such as 1,2-benzendiol, 2 chemical compounds which had a heterocyclic structure and Ostructure, such as $\alpha$.- $D$-Glucopyranose, 4,6-O-ethylidene, and 1 chemical compound which had a cyclic structure, $\mathrm{O}$-structure, and $\mathrm{N}$-structure, i.e., $\mathrm{N}, \mathrm{N}$-dimethyl-L-homoserine lactone. Chemical compounds with these functional groups can coat and inhibit the surface oxidation process of marine steel. 


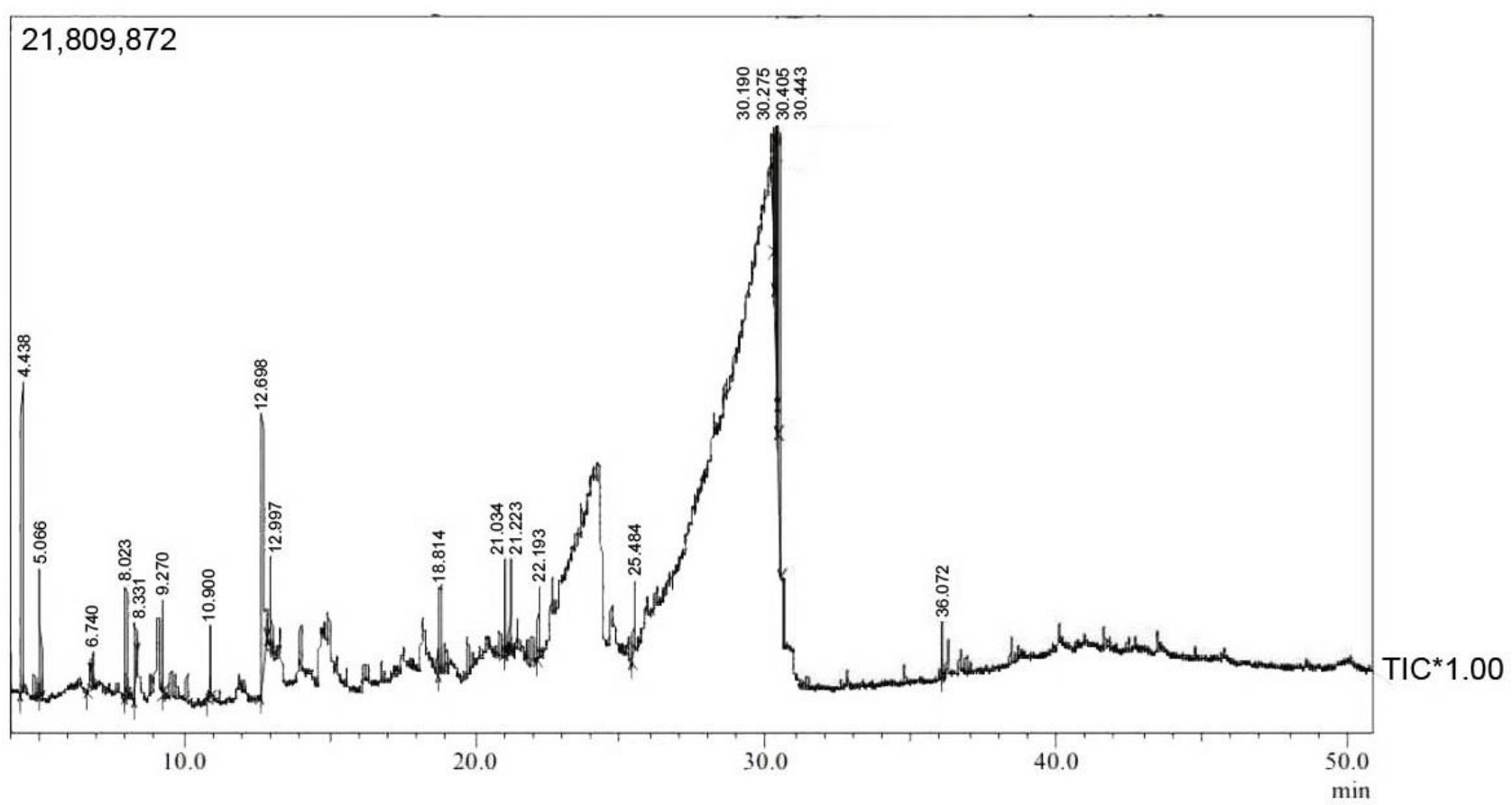

Figure 2. The GC-MS test results of Rhizophora mucronata leaves extract.

Table 1. Chemical composition based on GC-MS test results of Rhizophora mucronata leaves extract.

\begin{tabular}{|c|c|c|c|c|}
\hline Peak & $\begin{array}{l}\text { Ret.Time } \\
\text { (minutes) }\end{array}$ & $\begin{array}{c}\text { Conc. } \\
(\%)\end{array}$ & Chemical name & Chemical structure \\
\hline
\end{tabular}

\begin{tabular}{|c|c|c|c|c|}
\hline 1 & 4.438 & 8.37 & $\begin{array}{l}\text { Cyclopentyl 4-ethylbenzoate } \\
\text { (4-Ethylbenzoic acid, } \\
\text { cyclopentyl ester) }\end{array}$ & $\begin{array}{c}\text { Cyclic structure } \\
\text { O-structure }\end{array}$ \\
\hline 2 & 5.066 & 2.69 & 2-Oxepanone & $\begin{array}{c}\text { Cyclic structure } \\
\text { O-structure }\end{array}$ \\
\hline 3 & 6.740 & 1.61 & $2 H$-Pyran-2,6(3H)dione & $\begin{array}{c}\text { Cyclic structure } \\
\text { O-structure }\end{array}$ \\
\hline
\end{tabular}




\begin{tabular}{cccccc} 
Peak & $\begin{array}{c}\text { Ret.Time } \\
(\text { minutes })\end{array}$ & $\begin{array}{c}\text { Conc. } \\
(\%)\end{array}$ & Chemical name & Chemical structure & $\begin{array}{c}\text { Functional } \\
\text { chemical } \\
\text { structure }\end{array}$ \\
\hline & 8.023 & 2.41 & Cyclotrisiloxane & &
\end{tabular}

$58.331 \quad 2.13 \quad \begin{gathered}N, N \text {-Dimethyl-L-homoserine } \\ \text { lactone }\end{gathered}$




\begin{tabular}{|c|c|c|c|c|c|}
\hline Peak & $\begin{array}{l}\text { Ret.Time } \\
\text { (minutes) }\end{array}$ & $\begin{array}{c}\text { Conc. } \\
(\%)\end{array}$ & Chemical name & Chemical structure & $\begin{array}{c}\text { Functional } \\
\text { chemical } \\
\text { structure }\end{array}$ \\
\hline
\end{tabular}

$10 \quad 18.814 \quad 3.29 \quad 4-t$-Pentylcyclohexene

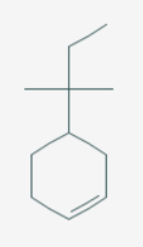

Cyclic structure

$1121.0342 .01 \quad \begin{gathered}\text { 3-Methyl-4-methylene-2- } \\ \text { hexanone }\end{gathered}$

$\begin{array}{llll}12 & 21.223 & 2.17 & \text { Neoclovene }\end{array}$

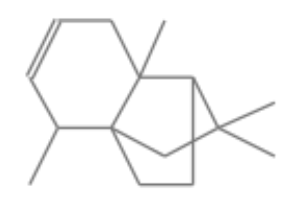

Heterocyclic structure

$13 \quad 22.193 \quad 1.75 \quad$ Megastigmatrienone

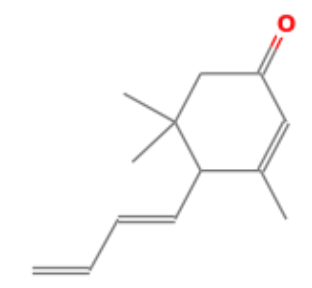

Cyclic structure $\mathrm{O}$-structure
14
$25.484 \quad 2.58$
2,3-Bis(1-
methylallyl)pyrrolidine

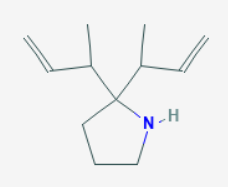
Cyclic structure $\mathrm{N}$-structure 


\begin{tabular}{|c|c|c|c|c|c|}
\hline Peak & $\begin{array}{l}\text { Ret.Time } \\
\text { (minutes) }\end{array}$ & $\begin{array}{c}\text { Conc. } \\
(\%)\end{array}$ & Chemical name & Chemical structure & $\begin{array}{c}\text { Functional } \\
\text { chemical } \\
\text { structure }\end{array}$ \\
\hline 15 & 30.190 & 3.24 & $\begin{array}{l}\text { Dimethyl 4- } O \text { - } \\
\text { methylhexopyranosiduronate }\end{array}$ & & $\begin{array}{c}\text { Cyclic structure } \\
\text { O-structure }\end{array}$ \\
\hline 16 & 30.275 & 2.89 & $\begin{array}{l}\text { 4,6- } O \text {-Ethylidene- } \alpha .-D \text { - } \\
\text { glucopyranose }\end{array}$ & & $\begin{array}{l}\text { Heterocyclic } \\
\text { structure } \\
\text { O-structure }\end{array}$ \\
\hline 17 & 30.370 & 14.04 & 3-O-Methyl-D-glucose & & O-structure \\
\hline 18 & 30.405 & 4.55 & 4-O-Methylmannose & & $\begin{array}{c}\text { Cyclic structure } \\
\text { O-structure }\end{array}$ \\
\hline 19 & 30.443 & 22.04 & $\begin{array}{l}\text { 2-O-Methyl- } D \text { - } \\
\text { mannopyranosa }\end{array}$ & & O-structure \\
\hline
\end{tabular}




\begin{tabular}{cccccc}
\hline Peak & $\begin{array}{c}\text { Ret.Time } \\
(\text { minutes })\end{array}$ & $\begin{array}{c}\text { Conc. } \\
(\%)\end{array}$ & Chemical name & Chemical structure & $\begin{array}{c}\text { Functional } \\
\text { chemical } \\
\text { structure }\end{array}$ \\
\hline & 36.072 & 1.44 & Isosteviol methyl ester & & $\begin{array}{c}\text { Heterocyclic } \\
\text { structure } \\
\text { O-structure }\end{array}$ \\
\hline
\end{tabular}

\subsection{Marine steel Plates Characteristics}

The marine steel elements determined by emission spectroscopy are listed in Table 2 .

Table 2. Elemental composition of marine steel plates.

\begin{tabular}{cc}
\hline Elements & Percentage (\%) \\
\hline $\mathrm{Fe}$ & 98.56 \\
$\mathrm{Si}$ & 0.260 \\
$\mathrm{C}$ & 0.316 \\
$\mathrm{Al}$ & 0.035 \\
$\mathrm{Mn}$ & 0.655 \\
$\mathrm{Mo}$ & 0.038 \\
$\mathrm{P}$ & 0.024 \\
$\mathrm{~V}$ & 0.044 \\
\hline
\end{tabular}

1040 steel for marine use contains $98.58 \% \mathrm{Fe}, 0.40 \% \mathrm{C}, 0.23 \% \mathrm{Si}$ and $0.65 \% \mathrm{Mn}$ [10]. A steel with high carbon content will be easily corroded [11]. The corrosion resistance of steel tends to increase due to silicon [12] and manganese [13].

\subsection{Polarisation study}

Based on the observations, the paint mixture with Rhizophora mucronata leaves extract can completely coat the surface of the marine steel. A good inhibitor can coat and prevent corrosion on marine steel surface perfectly [14]. The effect of Rhizophora mucronata leaves extract mixed with paint as a corrosion inhibitor on marine steel in $3.5 \% \mathrm{NaCl}$ solution can be seen in the following Tafel plot. 


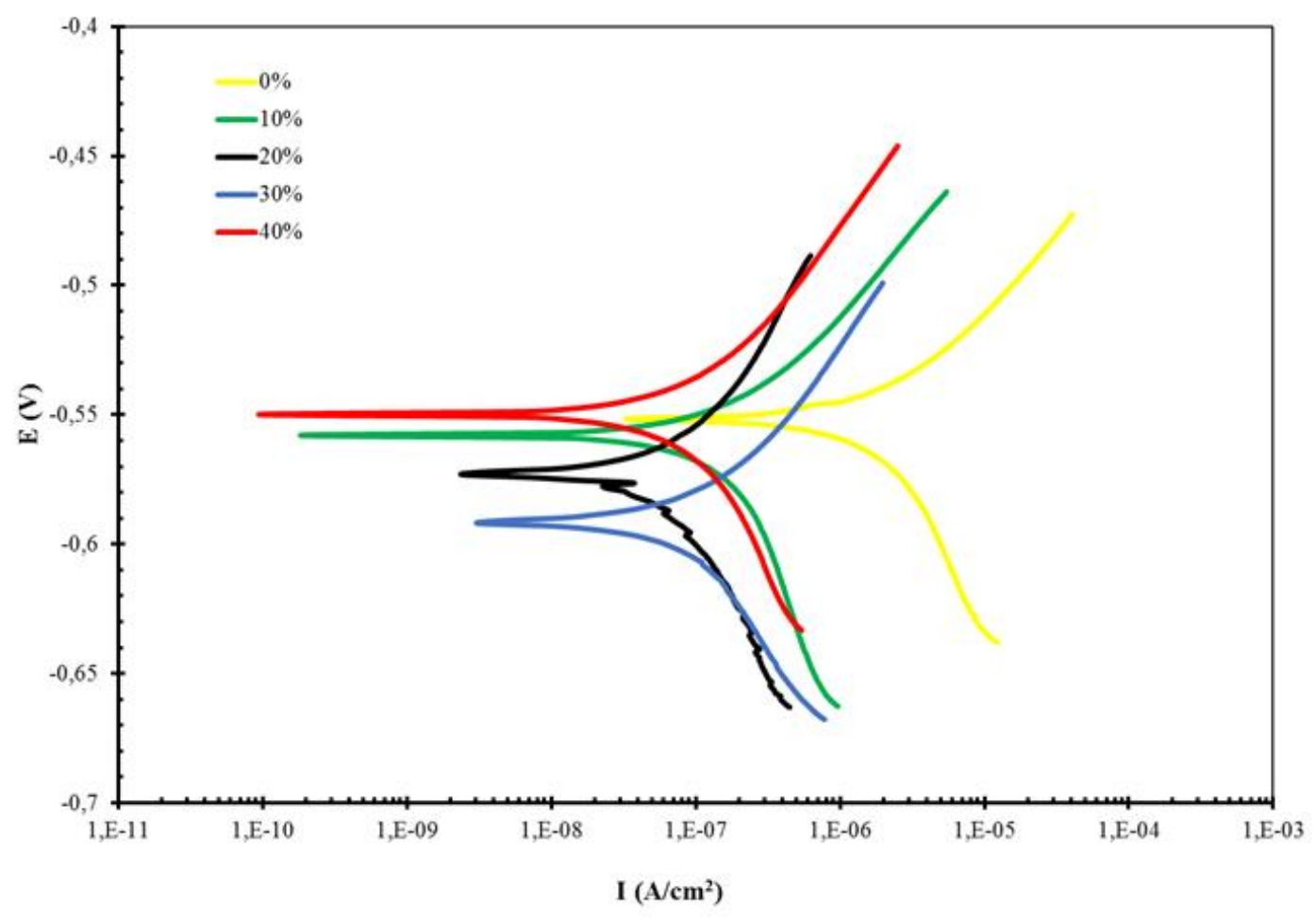

Figure 3. Tafel plot corrosion test of Rhizophora leaves extract mixed with paint in $3.5 \% \mathrm{NaCl}$ solution.

The Tafel plot of marine steel coated with paint only is on the right, while the Tafel plot of marine steel coated with a mixture of paint and Rhizophora leaves extract tends to approach the anodic side or lower current density. A lower current density indicates that the corrosion reaction is smaller [15], which means the inhibitor successfully prevents corrosion. Marine steel surfaces coated with inhibitors have a lower polarization curve compared to uncoated marine steel inhibitors [16].

The values of $E_{\text {corr }}, I_{\text {corr }}$, and \% IE from the test specimens coated with a mixture of paint and Rhizophora mucronata leaves extract are shown in Table 4.

Table 4. Effect of paint mixture with Rhizophora mucronata leaves extract at various concentrations.

\begin{tabular}{ccccc}
\hline $\begin{array}{c}\text { Inhibitor concentration } \\
(\boldsymbol{\%})\end{array}$ & $\boldsymbol{I}_{\text {corr }}\left(\boldsymbol{\mu A} \mathbf{A} \mathbf{c m}^{2}\right)$ & $\boldsymbol{E}_{\text {corr }}(\mathbf{m V})$ & $\begin{array}{c}\text { Corr. rate } \\
(\mathbf{m m} / \mathbf{y e a r})\end{array}$ & $\boldsymbol{\%} \mathbf{I E}$ \\
\hline 0 & 1.4073 & -704 & $10.84 \times 10^{-3}$ & 0.00 \\
10 & 0.0301 & -677 & $0.23 \times 10^{-3}$ & 97.86 \\
20 & 0.0259 & -712 & $0.20 \times 10^{-3}$ & 98.16 \\
30 & 0.0217 & -709 & $0.17 \times 10^{-3}$ & 98.46 \\
40 & 0.0146 & -750 & $0.11 \times 10^{-3}$ & 98.96 \\
\hline
\end{tabular}


Marine steel without being coated with an inhibitor had a corrosion rate of $10.84 \times 10^{-3} \mathrm{~mm} /$ year in a $3.5 \% \mathrm{NaCl}$ solution. In comparison, steel without a coating immersed in seawater has a corrosion rate of $0.07 \pm 0.02 \mathrm{~mm} / \mathrm{year}$ [17]. Marine steel is easily corroded because it is used in marine waters with a high corrosion rate, so it is necessary to apply a coating comprising a corrosion inhibitor.

Marine steel was coated with a mixture of paint with Rhizophora leaves extract, and the corrosion inhibitor reduced the corrosion rate from $0.23 \times 10^{-3}$ to $0.11 \times 10^{-3} \mathrm{~mm} /$ year in $3.5 \% \mathrm{NaCl}$ solution. The paint mixture with henna extract as a natural inhibitor has a corrosion rate of aluminum at 0.003846 to $0.001767 \mathrm{~mm} /$ year [18]. The addition of Rhizophora leaves extract concentrate to the paint mixture decreased the corrosion rate of marine steel and increased the inhibitor efficiency.

The corrosion potential ( $\left.E_{\text {corr }}\right)$ of plates coated with a mixture of paint with Rhizophora leaves extract is almost unchanged compared to those that are not coated. This shows that the mixture of paint with Rhizophora leaves extract protects the plate against corrosion attack. $I_{\text {corr }}$ values were found to decrease on the surface of the tested plates. \%IE increases with increasing mangrove extract concentration. The paint-coated specimens with all various concentrations of Rhizophora mucronata leaves extract had almost the same percentage increase in inhibitor efficiency (\% IE), 97.86-98.96\%. Therefore, the use of a mixture of paint with $20 \%$ Rhizophora mucronata leaves extract was taken as the optimal concentration.

\subsection{Marine steel surface microscopic structure}

Microscopic pictures of the marine steel specimen surface after the corrosion testing can be seen in Figure 4, where " $0 \%$ test specimen" means a specimen coaed with the paint with no corrosion inhibitor and " $10 \%$ test specimen" means a specimen coated with $90 \%$ paint + $10 \%$ mangrove extract.

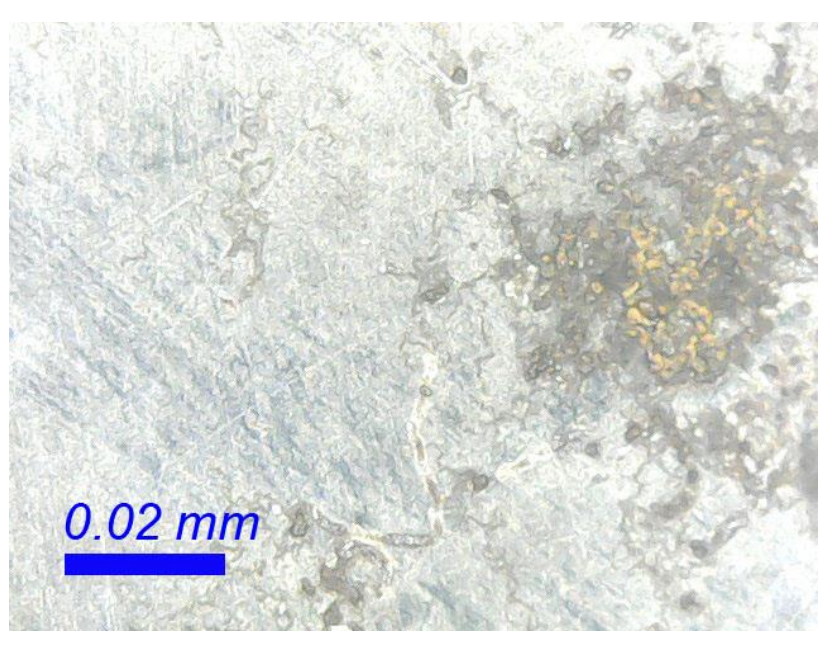

(a)

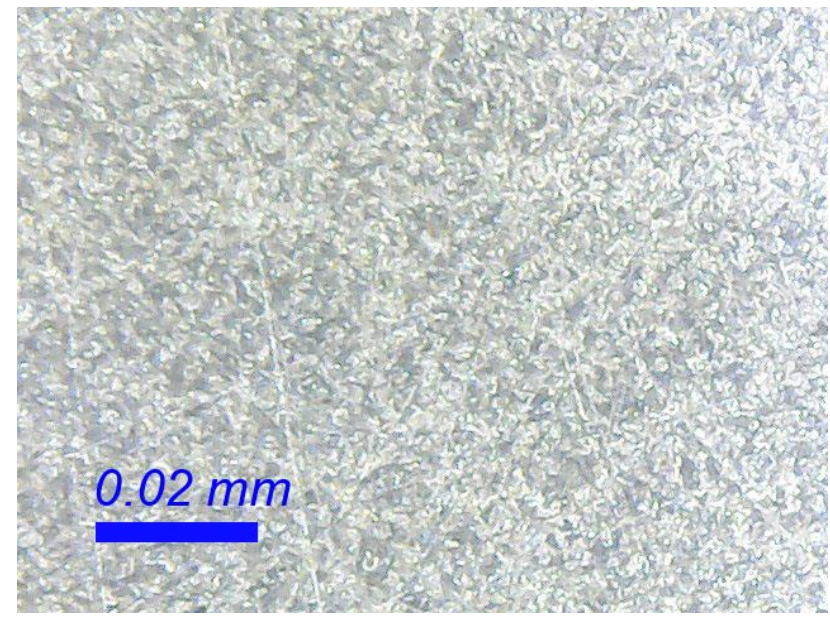

(b)

Figure 4. (a). Microscopic picture of $0 \%$ test specimen after polarisation study. (b). Microscopic picture of $10 \%$ test specimen after polarisation study. 
Corrosion on metal surfaces can be seen using an optical microscope [19]. Based on Figure 4, the $0 \%$ test specimen showed a corroded steel surface. Corroded steel is marked with a brownish colour [20], which is due to the iron element being oxidized [21]. While the $10 \%$ test specimen, the steel surface is coated with inhibitors, so the mixture of paint with Rhizophora leaves extract can minimize corrosion. A steel surface covered with an inhibitor can prevent corrosion [22].

\section{Conclusion}

Based on the GC-MS test result, Rhizophora mucronata leaves extract as natural corrosion inhibitor contains 11 chemical compounds which had cyclic structure and O-structure, 2 chemical compounds which had heterocyclic structure and O-structure, and 1 chemical compound which had cyclic structure, O-structure, and $\mathrm{N}$-structure. Based on emission spectroscopy, marine steel contain $98.56 \% \mathrm{Fe}, 0.316 \% \mathrm{C}, 0.26 \mathrm{Si}$ and $0.655 \mathrm{Mn}$. The paint mixture with Rhizophora mucronata leaves extract can completely coat the surface of the marine steel. On marine steel coated with a mixture of paint with Rhizophora mucronata leaves extract, and corrosion inhibitor reduced the corrosion rate $0.23 \times 10^{-3}$ to $0.11 \times 10^{-3} \mathrm{~mm} /$ year in $3.5 \% \mathrm{NaCl}$ solution. The paint-coated specimens with all concentrations of Rhizophora mucronata leaf extract had almost the same percentage increase in inhibitor efficiency (\% IE), 97.86-98.96\%. Therefore, the use of a mixture of the paint with $20 \%$ Rhizophora mucronata leaves extract was taken as the optimal concentration.

\section{References}

1. OECD. Perspectives on steel by steel-using industries, DSTI/SU/SC, 2010, 4 68th Steel Committee Meeting, Paris, 6-7 May 2010.

2. M. Abbas and M. Shafiee, An overview of maintenance management strategies for corroded steel structures in extreme marine environments, Mar. Struct., 2020, 71 (March 2019), 102718. doi: 10.1016/j.marstruc.2020.102718

3. E.M.E. Mansour, A.M. Abdel-Gaber, B.A.Abd-El Nabey, N. Khalil, E. Khamis, A. Tadros, H. Aglan and A. Ludwick, Developing and testing of a new anti-corrosive coating containing algae as a natural inhibitor for preventing marine corrosion of steel, Corrosion, 2003, 59, no. 3, 242-249. doi: 10.5006/1.3277557

4. S. Marzorati, L. Verotta and SP. Trasatti, Green Corrosion Inhibitors from natural sources and biomass waste, Molecules, 2019, 24, 48.

5. A. Salhi, A. Bouyanzer, A. Chetouani, E.El Ouariachi, A. Zarrouk, B. Hammouti, J.M. Desjobert and J. Costa, Chemical Composition, Antioxidant and Corrosion Activities of Mentha suaveolens, JMES, 2017, 8, no. 5, 1718-1728.

6. N.A.Z. Abidin, N.H.A. Halim and R. Me, Basic study of chemical constituents in Rhizophora species, The open conference proceedings journal, 2013, 4 (Suppl-2, M7), $27-28$. 
7. O.S.I. Fayomi, A.P.I. Popoola, L.R. Kanyane and T. Monyai, Development of Reinforced in-situ anti-corrosion and Wear Zn-TiO2/ZnTiB2 Coatings on Mild Steel, Results Phys., 2017, 7, 644-650.

8. J. Xu, S. Du, X. Yang, Y. Hao and X. Wang, Molecular dynamics simulation of the effects of different salts on methane hydrate formation: An analysis of $\mathrm{NaCl}, \mathrm{KCl}$ and CaCl2, IOP Conf. Ser.: Earth Environ. Sci., 2021, 675, no. 1. doi: 10.1088/1755$1315 / 675 / 1 / 012180$

9. J.A. Rodríguez, J. Cruz-Borbolla, P.A. Arizpe-Carreón and E. Gutiérrez, Mathematical models generated for the prediction of corrosion inhibition using different theoretical chemistry simulations, Materials, 2020, 13, no. 24, 1-34. doi: $10.3390 / \mathrm{ma1} 3245656$

10. A. Çalik, Effect of cooling rate on hardness and microstructure of AISI 1020, AISI 1040, and AISI 1060 Steels, Int. J. Phys. Sci., 2009, 4, no. 9, 514-518.

11. M.A. Hafeez, A. Inam and A. Farooq, Mechanical and corrosion properties of medium carbon low alloy steel after cyclic quenching and tempering heat-treatments, Mater. Res. Express, 2020, 7, no. 1, 0-12. doi: 10.1088/2053-1591/ab6581

12. H.E. Townsend, Effects of alloying elements on the corrosion of steel in industrial atmospheres, Corrosion, 2001, 57, no. 6, 497-501. doi: 10.5006/1.3290374

13. Y. Hyun, and H. Kim, Effects of alloying elements (Cr, Mn) on corrosion properties of carbon steel in synthetic seawater, J. Korean Inst. Metals Mater., 2016, 54, no. 2, 6878. doi: 10.3365/KJMM.2016.54.2.68

14. M. Taghavikish, N.K. Dutta and N.R. Choudhury, Emerging Corrosion Inhibitors for Interfacial Coating, Coatings, 2017, 7, no. 12, 217. doi: 10.3390/coatings 7120217

15. B.N. Popov, Electrochemical Kinetics of Corrosion, Corrosion Engineering, Ch. 3, 2015. doi: $10.1016 / \mathrm{b} 978-0-444-62722-3.00003-3$

16. O. Gomez, H. Aponte, E. Vera and Y. Pineda, Evaluation of Corrosion inhibitor simulating Conditions of Operation, J. Phys. Conf. Ser., 2017, 935. doi: $10.1088 / 1742-$ $\underline{6596 / 935 / 1 / 012060}$

17. P. Refait, A.M. Grolleau, M. Jeannin, C. Rémazeilles and R. Sabot, Corrosion of Carbon Steel in Marine Environments: Role of the Corrosion Product Layer, Corros. Mater. Degrad., 2020, 1, no. 1, 198-218. doi: 10.3390/cmd1010010

18. W.B. Wan Nik, H.M. Hajar, M.J. Suriani, M.G.M. Sabri and M.J. Ghazali, Development of anti-corrosive paint incorporated with henna extract as a natural inhibitor, J. Mech. Eng. Sci., 2017, 11, no. 4, 3179-3188. doi: 10.15282/jmes.11.4.2017.20.0286

19. O. Oudbashi, S.M. Emami, H. Ahmadi and P. Davami, Micro-stratigraphical investigation on corrosion layers in ancient Bronze artefacts by scanning electron microscopy energy dispersive spectrometry and optical microscopy, Heritage Sci., 2013, 1, no. 1, 1-10. doi: 10.1186/2050-7445-1-21

20. X. Yan, W. Di, T. Yingfeng, H. Minqiu and S. Hai, Experimental studies on mechanical properties of corroded steel bars after elevated temperature, Procedia Eng., 2017, 210, 622-629. doi: 10.1016/j.proeng.2017.11.122 
21. S. Karthick, S. Muralidharan and V. Saraswathy, Corrosion performance of mild steel and galvanized iron in clay soil environment, Arabian J. Chem., 2020, 13, no. 1, 33013318. doi: $10.1016 /$ j.arabjc.2018.11.005

22. K. Tamalmani and H. Husin, Review on corrosion inhibitors for oil and gas corrosion issues, Appl. Sci., 2020, 10, no. 10. doi: 10.3390/APP10103389 